\title{
ANALISIS TINGKAT KESUKAAN KONSUMEN TERHADAP JENIS IKAN YANG BERBEDA PADA KERUPUK STIK IKAN
}

\author{
(Analysis Of Consumer Preference Level Of Fish Types That Are Different On Fish Stick \\ Crackers)
}

\author{
Vita Yanuar \\ Program Studi Manajemen Sumber Daya Perairan \\ Fakultas Pertanian Universitas Antakusuma \\ Jl. Iskandar No. 63 Telp. 0532-22287 Kode Pos 74112 Pangkalan Bun \\ E-mail: vitayanuar15@gmail.com
}

Article Submitted: 27-08-2020

Article Accepted : 14-09-2020

\begin{abstract}
West Kotawaringin Regency's fishery products, both in fresh and processed form, are increasingly in demand by the market. This increase in demand is indeed expected given the high potential of fishery products in the West Kotawaringin Regency. Fisheries products in fresh form can experience quality deterioration. Therefore it is necessary to maintain quality by proper handling so that the fish stays fresh and is processed into processed products. Fish stick crackers is one of the processed products chosen as a form of food diversification business. The purpose of this study was to determine the level of consumer preference for fish stick crackers with different raw fish ingredients. The method used in this research is quantitative descriptive. This research was conducted with a purposive sampling method. The sample in this study was fish stick crackers with different types of fish (mackerel, remang and manyung) as the main raw material. This research was conducted by distributing questionnaires. The data obtained is then processed with ANOVA (Analysis of Variance) and further tests with the Tukey Test. ANOVA test results showed that the value of Fhit (15.092) > Ftab (3.16) and strengthened with a value of $\mathrm{p}<0.05$. This shows that there is a real difference in the level of preference for Total Hedonic of the three fish species. The hedonic test results (the level of preference) on the three types of fish stick crackers from fish raw materials which differ in terms of color, taste, aroma, and texture are the Mackerel fish stick crackers preferred with the total value of mackerel hedonic (5.88), remang (4.98), and manyung (5.18).
\end{abstract}

Keyword: fish stick crackers, preference level, hedonic test.

\section{PENDAHULUAN}

Kabupaten Kotawaringin Barat merupakan salah satu daerah yang mempunyai banyak sekali jenis usaha makanan ringan, dan salah satunya adalah kerupuk stik ikan yang bahan baku utamanya terbuat dari daging ikan tenggiri. Menurut Ariani (1999), diversifikasi konsumsi pangan telah dicanangkan pemerintah Indonesia lebih dari setengah abad. Ini bertujuan untuk menganekaragamkan bahan pangan yang menjadi konsumsi masyarakat untuk memenuhi kebutuhan gizinya dalam meningkatkan kualitas sumber daya manusia Indonesia. Perwujudan dari upaya ini 
dengan memanfaatkan pangan lokal yang tersedia.

Kerupuk stik ikan merupakan salah satu produk olahan yang dipilih sebagai bentuk usaha diversifikasi pangan. Pembuatan kerupuk stik ikan dengan memanfaatkan ikan tenggiri sebagai bahan baku ikan. Selain itu, ikan-ikan yang bernilai ekonomis seperti remang dan manyung juga digunakan sebagai pembanding dalam pembuatan kerupuk stik ikan. Kerupuk stik ikan merupakan makanan ringan yang berbahan dasar dari daging ikan, memiliki rasa yang gurih khas ikan dan tekstur yang renyah. Kerupuk stik ikan termasuk salah satu inovasi produk olahan dari ikan, yang awalnya tidak menggunakan bahan baku ikan tetapi hanya bahan baku tepung terigu saja dan bumbubumbu. Menurut Nurhayati (2015), kerupuk stik ikan dibuat dengan cara menghaluskan daging ikan, pembuatan adonan, pemipihan adonan, pencetakan, penggorengan, dan pengemasan produk.

Uji kesukaan juga disebut uji hedonik. Panelis dimintakan tanggapan pribadinya tentang kesukaan atau sebaliknya (ketidaksukaan). Disamping panelis mengemukakan tanggapan senang, suka atau kebalikannya, mereka juga mengemukakan tingkat kesukaannya. Tingkat-tingkat kesukaan ini disebut skala hedonik (Setyaningsih dkk. 2010). Skala hedonik dapat direntangkan atau diciutkan menurut rentangan skala yang dikehendaki. Skala hedonik dapat juga diubah menjadi skala numerik dengan angka mutu menurut tingkat kesukaan. Dengan data numerik ini dapat dilakukan analisis secara statistik. Penggunaan skala hedonik pada prakteknya dapat digunakan untuk mengetahui perbedaan. Uji hedonik banyak digunakan untuk menilai produk akhir. Penilaian dalam uji hedonik ini bersifat spontan. Ini berarti panelis diminta untuk menilai suatu produk secara langsung saat itu juga pada saat mencoba (Soekarto 1985).

\section{METODE PENELITIAN}

\section{Waktu dan Tempat}

Penelitian ini dilaksanakan di Kabupaten Kotawaringin Barat, di antaranya untuk pengolahan kerupuk stik ikan di UKM Nurhayati dan pengujian hedonik kerupuk stik ikan dilaksanakan di Fakultas Pertanian Universitas Antakusuma Pangkalan Bun (kepada mahasiswa), Dinas Kelautan dan Perikanan (kepada karyawan), dan SMK Harapan Pangkalan Bun (kepada pelajar).

\section{Bahan dan Alat Penelitian}

Bahan dan alat penelitian yang digunakan antara lain:.Pengolahan kerupuk stik ikan, bahan-bahan yang digunakan berupa tepung, daging ikan, bawang putih, telur, merica, ketumbar, garam, gula, penyedap rasa, minyak goreng, dan air. Alatalat yang digunakan antara lain baskom, blender, penggilingan mie, timbangan, dan botol untuk memipihkan adonan. Untuk Uji hedonik, bahannya adalah kerupuk stik ikan dengan 3 bahan baku ikan yang berbeda (ikan tenggiri, remang dan manyung) dan air putih. Alat untuk uji hedonik terdiri dari kuisioner uji hedonik, bolpoin dan piring kecil.

\section{Metode Penelitian}

Metode dasar yang digunakan dalam penelitian ini adalah metode deskriptif kuantitatif. Metode deskriptif kuantitatif bertujuan untuk mengetahui hubungan antara dua variabel atau lebih yang bertujuan untuk memperoleh deskripsi atau gambaran mengenai kualitas produk kerupuk stik ikan yang kemudian datanya dianalisis dengan ANOVA.

\section{Teknik Pengambilan Sampel}

Penelitian ini menggunakan metode sampling yaitu purposive sampling dengan menyebarkan angket ke 60 panelis tidak terlatih untuk mendapatkan hasil uji hedonik. Sampel dilakukan kepada 60 orang panelis yang terdiri dari 20 orang mahasiswa, 20 orang karyawan dan 20 orang pelajar. Sugiyono (2002), purposive 
sampling adalah pengambilan sampel secara sengaja sesuai dengan persyaratan sampel yang diperlukan.

\section{Teknik Pengumpulan Data}

Teknik pengumpulan data yang akan digunakan adalah:

1. Angket (kuisioner)

Metode ini adalah dengan cara menyebarkan angket dan mengumpulkan data dari berbagai pertanyaan tertulis yang digunakan untuk memperoleh informasi dari responden. Kuisioner dibagikan kepada 20 orang mahasiswa Fakultas Pertanian Universitas Antakusuma, 20 orang karyawan Dinas Kelautan dan Perikanan, serta 20 orang pelajar SMK Harapan Pangkalan Bun. Kriteria skor pada pengujian hedonik adalah sangat suka (7), suka (6), agak suka (5), netral (4), agak tidak suka (3), tidak suka (2), dan sangat tidak suka (1).

2. Survei

Survei adalah teknik pengumpulan informasi yang dilakukan dengan cara menyusun daftar pertanyaan yang diajukan pada responden berbentuk sampel dalam sebuah populasi. Dalam penelitian ini survei dilakukan di Fakultas Pertanian Universitas Antakusuma (mahasiswa), Dinas Kelautan dan Perikanan (karyawan), dan
SMK Harapan Pangkalan Bun (pelajar).

3. Studi Literatur

Pengumpulan informasi yang berhubungan dengan teori-teori yang berkaitan dengan masalah variabel yang diteliti. Studi literatur tersebut diperoleh dari laporan penelitian, jurnal elektronik, dan buku.

4. Wawancara

Wawancara dilakukan melalui teknik komunikasi langsung kepada pihak yang bersangkutan. Wawancara ini dilakukan kepada pemilik usaha pengolahan hasil perikanan UKM Nurhayati.

\section{Teknik Analisis Data}

Teknik analisis data meliputi:

a. Hasil yang telah diperoleh dari uji hedonik ditabulasikan dan dihitung total perlakuan (Yi.), total kelompok (Y,j), total umum (Y..) dan dihitung pula $\sum \mathrm{Y}^{2}$ untuk setiap perlakuan dari kelompok.

b. Kemudian dilakukan analisis varian dengan ANOVA (Analysis of Variance) menggunakan SPSS 16.0 untuk mengetahui adanya perbedaan antara sampel satu dengan sampel yang lainnya.

c. Jika terdapat perbedaan hasil antara sampel maka dilakukan uji lanjut dengan Uji Tukey menggunakan SPSS 16.0. 
Proses Pengolahan Kerupuk Stik Ikan

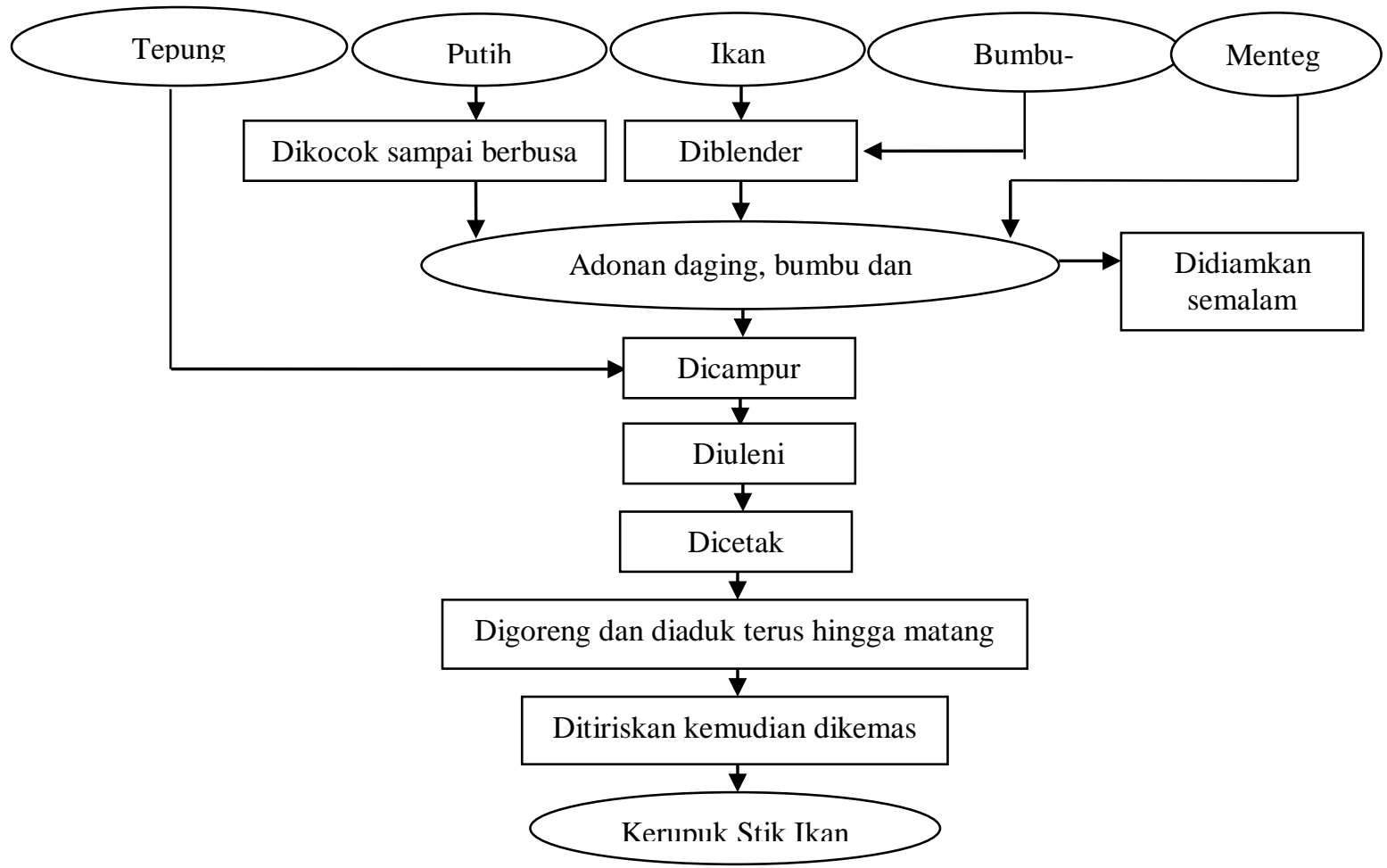

Gambar 1. Diagram Alir Proses Pengolahan Kerupuk Stik Ikan (Nurhayati 2015).

HASIL DAN PEMBAHASAN

Karakteristik Uji Hedonik Kerupuk Stik

Ikan

Karakteristik uji hedonik dalam penelitian ini yaitu pengujian kerupuk stik ikan dengan bahan baku ikan yang berbeda dengan empat karakteristik penilaian meliputi warna, aroma, rasa, dan tekstur. Hasil rerata uji hedonik kerupuk stik ikan dapat dilihat pada Tabel 1 .

Tabel 1. Rerata Uji Hedonik Kerupuk Stik Ikan Remang, Manyung dan Tenggiri

\begin{tabular}{lccccc}
\hline & Warna & Rasa & Aroma & Tekstur & $\begin{array}{c}\text { Rerata } \\
\text { Hedonik }\end{array}$ \\
\hline Remang & 5,15 & 5,35 & 4,78 & 4,62 & 4,98 \\
Manyung & 5,22 & 5,10 & 4,92 & 5,50 & 5,18 \\
Tenggiri & 5,73 & 6,10 & 5,60 & 6,08 & 5,88 \\
\hline
\end{tabular}

Sumber: Data diolah ( 2020).

\section{Karakteristik Warna Kerupuk Stik Ikan}

Berdasarkan Tabel 1, nilai rata-rata kesukaan terhadap warna kerupuk stik ikan remang sebesar 5,15, kerupuk stik ikan manyung sebesar 5,22 dan kerupuk stik ikan tenggiri sebesar 5,73. Berdasarkan hasil uji ANOVA menyatakan bahwa nilai $\mathrm{F}_{\text {hit }}(3.873)$ $>\mathrm{F}_{\text {tab }}(3,16)$, dan diperkuat nilai $\mathrm{p}<0,05$. Hal ini menunjukan adanya perbedaan nilai kesukaan panelis berdasarkan warna dari tiga jenis ikan yang berbeda. Dengan menggunakan uji beda terdapat perbedaan yang signifikan antara produk ikan remang dengan tenggiri. Namun jika dilihat dari nilai $\mathrm{p}<0,05$, tidak ada perbedaan baik antara ikan tenggiri dengan manyung maupun manyung dengan remang dengan $\mathrm{p}(0,06)>0,05$. 
Warna dapat memperbaiki dan memberikan daya tarik pada makanan, warna juga berpengaruh pada tingkat kesukaan produk. Suatu bahan makanan yang bernilai gizi, enak dan teksturnya sangat baik kurang disukai apabila mempunyai warna yang kurang menarik (Winarno 1997). Pada penelitian terhadap kerupuk stik ikan dengan jenis ikan yang berbeda menunjukan para penelis cenderung lebih menyukai warna stik ikan tenggiri karena warnanya yang putih cerah (kekuningan), jika dibandingkan dengan stik ikan remang yang putih pucat, dan stik ikan manyung yang berwarna sedikit kecoklatan.

Bahan baku yang digunakan juga mempengaruhi warna kerupuk stik ikan yang dihasilkan. Kerupuk stik ikan remang memiliki warna putih, hal ini dikarenakan daging ikan remang berwarna putih. Kerupuk stik ikan manyung berwarna kecoklatan, hal ini dikarenakan daging ikan manyung berwana kemerahan. Kerupuk stik ikan tenggiri berwarna putih kekuningan, hal ini dikarenakan daging ikan tenggiri berwarna putih kemerahan.

Kandungan asam amino pada daging ikan juga mempengaruhi warna kerupuk stik ikan (Lawrie 2003). Tingkat intensitas warna tergantung dari lama penggorengan, suhu penggorengan dan komposisi kimia pada permukaan luar bahan pangan (bahan baku ikan) (Kataren 1986).

\section{Karakteristik Aroma Kerupuk Stik Ikan}

Hasil uji hedonik (Tabel 1) didapatkan nilai rata-rata kesukaan terhadap aroma adalah sebesar 4,78 untuk kerupuk stik ikan remang, 4,92 untuk kerupuk stik ikan manyung sedangkan untuk kerupuk stik ikan tenggiri adalah 5,60. Hasil uji ANOVA menunjukan bahwa nilai $\mathrm{F}_{\text {hit }}(7,148)>$ $\mathrm{F}_{\mathrm{tab}}(3,16)$ dan diperkuat nilai $\mathrm{p}<0,05$. Hal ini menunjukan adanya perbedaan tingkat kesukaan berdasarkan aroma ikan dari tiga jenis ikan yang berbeda. Dengan menggunakan uji beda didapatkan bahwa terdapat perbedaan yang nyata antara kerupuk stik ikan remang dengan tenggiri $p(0,02)<0,05$, manyung dengan tenggiri $\mathrm{p}(0,10)<0,05$ namun demikian tidak terdapat perbedaan antara remang dengan manyung $\mathrm{p}(0,83)>0,05$.

Aroma merupakan nilai tambah pada suatu produk. Aroma yang terbaik didapat pada kerupuk stik ikan tenggiri. Hal ini dikarenakan aroma yang dihasilkan kerupuk stik ikan tenggiri sangat kuat (aroma khas ikan) jika dibandingkan dengan aroma kerupuk stik ikan lainnya (remang dan manyung). Salah satu faktor penting yang menjadi pertimbangan konsumen dalam memilih produk makanan adalah aroma. Winarno (1997) menyatakan bahwa dalam banyak hal, kelezatan makanan ditentukan oleh aroma atau bau dari makanan tersebut. Aroma yang menggugah selera akan menjadi parameter yang baik bagi konsumen untuk memilih produk tersebut. Rahayu et al. (1992), menyatakan aroma khas ikan tenggiri justru disukai konsumen.

\section{Karakteristik Rasa Kerupuk Stik Ikan}

Nilai rata-rata kesukaan terhadap rasa kerupuk stik ikan tenggiri sebesar 6,10 sedangkan untuk kerupuk stik remang sebesar 5,35 dan kerupuk stik ikan manyung sebesar 5,10. Hasil perhitungan ANOVA menunjukan bahwa nilai $F_{\text {hit }}(9,265)>$ $\mathrm{F}_{\text {tab }}(3,16)$ dan diperkuat nilai $\mathrm{p}(0,00)>0,05$, menyatakan bahwa dari karekteristik rasa kerupuk stik ikan menunjukan adanya perbedaan. Dari uji beda Tukey HSD remang dengan tenggiri tidak berbeda nyata ditunjukan dengan $p(0,06)>0,05$. Manyung dengan remang tidak berbeda nyata ditunjukan dengan nilai $p(0,56)>0,05$, manyung dengan tenggiri berbeda nyata ditunjukan dengan nilai $p(0,00)<0,05$.

Rasa merupakan tanggapan indera terhadap saraf, seperti manis, pahit, asam dan asin. Rasa pada produk sangat berpengaruh pada kesukaan seseorang. Dalam uji yang dilakukan terhadap 60 panelis menunjukan bahwa rata-rata panelis lebih menyukai rasa kerupuk stik ikan tenggiri daripada kerupuk stik remang dan kerupuk stik manyung. Kerupuk stik ikan 
tenggiri lebih disukai karena rasanya yang lebih gurih dan kekhasan daging ikannya. Menurut Suryaningrum dkk. (2002), cita rasa makanan dipengaruhi dari komponenkomponen yang terdapat di dalam makanan seperti protein, lemak, dan karbohidrat yang ada.

\section{Karakteristik Tekstur Kerupuk Stik Ikan}

Nilai rata-rata kesukaan terhadap tekstur kerupuk stik ikan tenggiri sebesar 6,08 sedangkan untuk kerupuk stik ikan manyung sebesar 5,50 dan untuk kerupuk stik ikan remang sebesar 4,62. Hasil uji ANOVA menunjukan bahwa nilai $F_{\text {hit }}(17,668)>F_{\text {tab }}(3,16)$ dan diperkuat dengan nilai $\mathrm{p}<0,05$. Hal ini menunjukan adanya tingkat perbedaan kesukaan terhadap tekstur ikan dari jenis ikan yang berbeda. Dari uji ANOVA dilanjutkan uji beda Tukey HSD dimana tedapat perbedaan nyata antara remang dengan manyung ditunjukan dengan $\mathrm{p}(0,001)<0,05$, remang dengan tenggiri berbeda nyata ditunjukan dengan $\mathrm{p}(0,00)<0,05$ namun demikian manyung dengan tenggiri tidak berbeda nyata ditunjukan dengan nilai $\mathrm{p}(0,052)>0,05$.

Tekstur dari kerupuk stik ikan dapat uji dengan dirasakan atupun disentuh.
Tekstur merupakan salah satu aspek penilaian dalam penampilan produk. Penelitian karakteristik tekstur menunjukan bahwa karakteristik tekstur kerupuk stik ikan tenggiri tidak berbeda nyata dengan kerupuk stik ikan manyung tetapi kerupuk stik ikan remang berbeda nyata dengan kerupuk stik ikan tenggiri. Tekstur yang lebih disukai panelis adalah stik ikan tenggiri. Hal ini dikarenakan tekstur kerupuk stik ikan tenggiri lebih halus dan renyah jika dibandingkan dengan kerupuk stik ikan remang yang memiliki tekstur yang lebih keras, namun demikian jika dibandingkan dengan kerupuk stik manyung dan kerupuk stik ikan tenggiri tidak berbeda nyata.

Penambahan bahan baku utama yang berbeda (daging ikan) sangat berpengaruh nyata terhadap tekstur kerupuk stik ikan. Hal ini dikarenakan tekstur pada ketiga daging ikan juga berbeda. Tekstur daging ikan remang lebih berserat dibandingkan dengan tekstur daging ikan manyung maupun daging ikan tenggiri. Tekstur kerupuk stik ikan tenggiri lebih renyah hal ini disebabkan ikan tenggiri yang tidak memiliki serat pada dagingnya (Wibowo 1995).

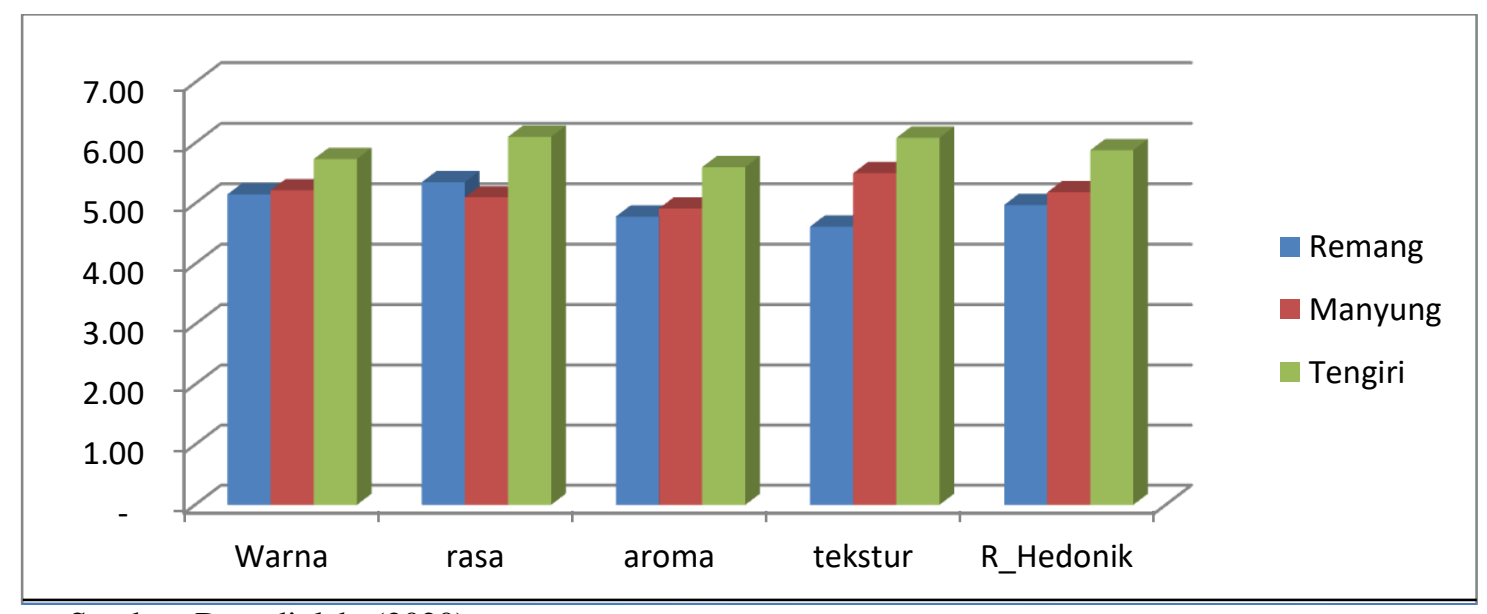

Sumber: Data diolah (2020).

Gambar 1. Grafik Rerata Uji Hedonik Stik Ikan Remang, Manyung dan Tenggiri

\section{Karakteristik Total Uji Hedonik Kerupuk Stik Ikan}

Berdasarkan Tabel 1, nilai rerata uji hedonik terhadap kerupuk stik ikan remang sebesar 4,98 sedangkan kerupuk stik ikan manyung sebesar 5,18 dan kerupuk stik ikan 
tenggiri 5,88. Lebih jelasnya, masingmasing karakteristik dan total uji hedonik dapat dilihat pada Gambar 1.

Hasil uji ANOVA menunjukan bahwa nilai $\mathrm{F}_{\text {hit }}(15,092)>\mathrm{F}_{\mathrm{tab}}(3,16)$ dan diperkuat dengan nilai $\mathrm{p}<0,05$. Hal ini menunjukan adanya perbedaan nyata tingkat kesukaan konsumen terhadap Total Hedonik dari ketiga jenis kerupuk stik ikan tersebut. Dari uji ANOVA dilanjutkan uji beda Tukey HSD maka didapatkan bahwa tidak terdapat perbedaan nyata antara kerupuk stik ikan remang dan kerupuk stik ikan manyung yang ditunjukan dengan $p(0,45)>0,05$, kerupuk stik ikan remang dan tenggiri berbeda nyata ditunjukan dengan $p(0,00)<0,05$. Sedangkan kerupuk stik ikan manyung dan kerupuk stik ikan tenggiri berbeda nyata ditunjukan dengan nilai $\mathrm{p}(0,00)<0,05$.

Berdasarkan Gambar 1, untuk semua karakteristik uji hedonik warna, aroma, rasa dan tekstur menunjukan bahwa kerupuk stik ikan tenggiri lebih banyak disukai dengan nilai rata-rata hedonik 5,88. Dari hasil uji hedonik terdapat perbedaan nyata antara kerupuk stik ikan tenggiri dan kerupuk stik ikan remang. Namun, untuk kerupuk stik ikan remang dan kerupuk stik ikan manyung tidak terdapat perbedaan nyata. Hasil dari semua parameter menunjukan bahwa kerupuk stik ikan tenggiri lebih banyak disukai dari segi warna, aroma, rasa, dan tekstur.

Hasil rata-rata uji hedonik kerupuk stik ikan dengan bahan baku yang berbeda menunjukan bahwa warna kerupuk stik ikan tenggiri lebih disukai dengan nilai rata-rata tertinggi 5,73 dibulatkan menjadi 6 (suka). Artinya panelis lebih menyukai kerupuk stik ikan tenggiri. Hal ini dikarenakan kerupuk stik ikan tenggiri memiliki warna yang putih cerah (tidak pucat) sehingga lebih menarik minat panelis.
Hasil rata-rata uji hedonik kerupuk stik ikan dengan bahan baku yang berbeda menunjukan bahwa aroma kerupuk stik ikan tenggiri lebih disukai dengan nilai rata-rata tertinggi 5,60 dibulatkan menjadi 6 (suka). Artinya panelis lebih menyukai kerupuk stik ikan tenggiri. Hal ini dikarenakan kerupuk stik ikan tenggiri memiliki aroma ikan yang kuat sehingga lebih menarik minat panelis. Menurut Rahayu dkk. (1992), aroma stik ikan tenggiri lebih disukai karena daging ikan tenggiri memiliki aroma yang khas.

Hasil rata-rata uji hedonik kerupuk stik ikan dengan bahan baku yang berbeda menunjukan bahwa rasa kerupuk stik ikan tenggiri lebih disukai dengan nilai rata-rata tertinggi 6,10 dibulatkan menjadi 6 (suka). Artinya panelis lebih menyukai kerupuk stik ikan tenggiri. Hal ini dikarenakan kerupuk stik ikan tenggiri memiliki rasa khas ikan yang kuat dan lebih gurih karena adanya protein yang terkandung di dalam daging ikan tenggiri.

Hasil rata-rata uji hedonik kerupuk stik ikan dengan bahan baku yang berbeda menunjukan bahwa tekstur kerupuk stik ikan tenggiri lebih disukai dengan nilai rata-rata tertinggi 6,08 dibulatkan menjadi 6 (suka). Artinya panelis lebih menyukai kerupuk stik ikan tenggiri. Hal ini dikarenakan kerupuk stik ikan tenggiri memiliki tekstur yang halus dan renyah jika dibandingkan dengan kerupuk stik ikan lainnya sehingga lebih menarik minat panelis.

Kerupuk stik ikan tenggiri lebih disukai dari kerupuk stik ikan remang dan kerupuk stik ikan manyung. Hal ini sesuai dengan pendapat Martosubroto dkk. (1991), ikan tenggiri (Scomberomorus commersoni) adalah jenis ikan air laut yang memiliki cita rasa khas sehingga digemari oleh masyarakat. Ikan tenggiri digemari oleh masyarakat karena rasa dagingnya yang gurih dan tidak amis bila dibandingkan dengan jenis 
ikan lainnya.

\section{KESIMPULAN}

1. Berdasarkan hasil total uji hedonik bahwa kerupuk stik ikan tenggiri lebih disukai oleh panelis dibandingkan kerupuk stik ikan lainnya, dengan nilai total hedonik kerupuk stik ikan tenggiri $(5,88)$ masuk dalam kategori $(6)$ yaitu suka.

2. Berdasarkan hasil uji hedonik bahwa kerupuk stik ikan remang $(4,98)$ dan stik ikan manyung $(5,18)$ masuk dalam kategori (5) agak disukai, yang artinya panelis agak menyukai kedua kerupuk stik ikan ini.

\section{DAFTAR PUSTAKA}

Ariani WD. 1999. Manajemen Kualitas. Edisi Pertama. Yogyakarta: Andi.

Ketaren S. 1986. Pengantar Teknologi Minyak dan Lemak Pangan. Cetakan Pertama. Jakarta: UI-Press.

Lawrie RA. 2003. Ilmu Daging. Penerjemah: Aminudin P. Meat Science. Jakarta: UI-Press.

Martosubroto P, Nurzali N, Malik AB. 1991. Potensi dan Penyebaran Sumber Daya Ikan Laut Di Perairan Indonesia. Jakarta: Ditjenkan Puslitbangkan Oseanologi.

Nurhayati. 2015. Stik Ikan. Kumai, Kotawaringin Barat: UKM Nurhayati.
Rahayu WP, S Maamoen, Suliantari, S Fardiaz. 1992. Teknologi Fermentasi Produk Perikanan. Bogor: Pusat Antar Universitas Pangan dan Gizi, Institut Pertanian Bogor.

Setyaningsih D, Apriyantono A, Sari MP. 2010. Analisis Sensori untuk Industri Pangan dan Agro. Bogor: IPB Press.

Soekarto. 1985. Penilaian Organoleptik untuk Industri Pangan dan Hasil Pertanian. Bogor: Pusat Pengembangan Teknologi Pangan IPB.

Sugiyono. 2002. Metode Penelitian Bisnis Informatika. Bandung: CV. Alfabeta.

Suryaningrum DT, Murdinah, Arifin M. 2002. Penggunaan kappa-karaginan sebagai bahan penstabil pada pembuatan fish meat loaf dari ikan tongkol (Euthynnus pelamys L). Jurnal Penelitian Perikanan Indonesia (Edisi Pasca Panen). Vol 8: 6.

Wibowo S. 1995. Bakso Ikan dan Bakso Daging. Jakarta: Penebar Swadaya.

Winarno FG. 1997. Kimia Pangan dan Gizi. Jakarta : Gramedia Pustaka. 